Nataša Bogavac-Cvetković

Milosav Miličković ${ }^{2}$

Faculty of Business and Industrial Management,

Union University-Nikola Tesla, Belgrade
SCIENTIFIC REVIEW ARTICLE doi:10.5937/ekonomika1602151B

Received: April 10, 2016 Accepted: May 19, 2016

\title{
THE IMPORTANCE OF CREATIVE AND INNOVATIVE SMALL AND MEDIUM ENTERPRISES IN OVERCOMINGOF CRISIS IN TERMS OF MODERN BUSINESS
}

\begin{abstract}
Creativity and innovations have become the true national wealth of the modern era. Future of the World which we operate in will be based on a completely new concept, so-called "innovation economy". In order to sustain the existence, growth and development in the times of crisis, it is imposed as necessary that small and medium-sized enterprises use intellectual and creative resources not only in developed butalso in developing countries.

The twenty-first century economies will be able to overcome crisis and progress if they accept creativity and innovations in accordance with changes. In the aforementioned processes, special emphasis is put on entrepreneurial creativity and innovations as elements of development policy and strategy of national economies.
\end{abstract}

Keywords: innovation, creativity, entrepreneurship, crisis, economy

Jel classification: A1, O310, G010

\section{УЛОГА КРЕАТИВНИХ И ИНОВАТИВНИХ МАЛИХ \\ И СРЕДЫИХ ПРЕДУЗЕЪА У ПРЕВАЗИЛАЖЕЊУ \\ КРИЗНИХ СТАЫА У УСЛОВИМА САВРЕМЕНОГ ПОСЛОВАЊА}

\begin{abstract}
Апстракт
Креативност и иноваџије су постали право нащионално богатство савременог доба. Будућност света у коме послујемо ће се заснивати на потпуно новом правиу тзв. Иновачијској привреди. У ичиу даљег опстанка, раста и развоја у условима кризе намеће се као нужност примена интелектуалних и креативних ресурса од стране малих и средњих предузећа не само у развијенијим већ и у земљама у развоју.

Привреде двадесет првог века ће бити у стању да превазилазе кризна стања и да напредују уколико у складу са променама прихватају креативност и иновачије. У поменутим процесима посебан значај се придаје преду-
\end{abstract}

\footnotetext{
${ }^{1}$ nacasn@hotmail.com

2 milickovicm@gmail.com
} 
зетничкој креативности и иновативности, као елементу развојне политике и статегије националних економија.

Кључне речи: иновативност, креативност, предузетништво, криза

\section{Introduction}

Both creativity and innovation of modern economy are pillars of the future growth and development. The creative economy gains the leading role under modern business conditions. It is an economy branch considerably contributing to realization of income and creation of new jobs, as well as to increase of exports. According to the Creative Economy Report 2013 (CERs) statistics, parts of the World intellectual and creative resources invested in culture based industries are considerably bigger in new millennium than before. Therefore, creative industries present a new model of economy featured by self-employment, autonomy and flexibility as well as by highly educated workforce.

According to the 2013 UNDP Report (UNDP/UNESCO, 2013, p. 20), "creative industry as a term refers to a wider productivity set including both goods and services made by the culture based industry and by industries subject to innovation, including many kinds of software research and development. The term was first used in the process of creation of policies such as Australian national culture policy of the early 1990s, as well as in the course of transition of the influential Department for Culture, Media and Sport of the United Kingdom from cultural to creative industries, at the end of the decade". The wider application of creative industry resulted from connection between creativity and both economic development and town planning.

One of the most outstanding XX century philosophers, J. Schumpeter, pointed at entrepreneurship as the key to economic prosperity as well as at the fact that cultural and institutional rules are important since they influence opinions referring to the ways of acting in economically profitable manner. Concerning the above, Schumpeter observed two problems of economic development. The first one relates to the fact that leaders realize considerable power in the course of business competition which makes them able to change rules in their favor as well as to block new business initiatives offering better products or better production processes. The second one is that the process of economic development itself leads into the process of superannuation of institutional regulation (Marklund, 2009, p. 11).

In his early papers Schumpeter praised the entrepreneur as "a hero", motivated and keen to create, to strive and to prove his superiority to others. Entrepreneurs are leaders ready to break antagonism within their environment in order to get innovations realized. Realization of innovations brings about many problems relevant to newly emerged situations. Innovations dictate, unlike the standard routine activities, numerous more active approaches of their agents. Whereas it is not possible to get all effects of a planned business anticipated, innovations do bring uncertainties about (Schumpeter, 1989, p. 85). In his later works he used to emphasize the notion that at the length of time innovation process is going to be more and more automated and red-taped, while individual work is going to be superseded by collective endeavor. 


\section{Creativity and entrepreneurship}

Creativity and entrepreneurship are points of interest of many researchers, chieflybecause of the impacts they make on employment, innovation and economic development. The relative literature gets these concepts analyzed both individually and altogether, depending on their treatment that could be realized either in the creative entrepreneurship context or out of it. Creative entrepreneurship actions could be analyzed starting from few aspects, the most important of which are the following: future profitability and growth, forms of employment, access to financial resources, market access and possibility of further education, specialization and training (Protogerou, Caloghirou \& Markou, 2015, p. 1).

Stimulation of profitability and growth is of special importance to entrepreneurship activities within creative industry. They are motivated,above all, by value making on financial, social, emotional and non-financial basis. Creative entrepreneurs are mainly led by their own ideas and are less oriented towards business activities as compared to archetype entrepreneurs, inter alia because they are less experienced in both managerial and growth stimulation activities. There are numerous empirical studies showing that, notwithstanding that many entrepreneurs involved in art businesses are able to survive, they are rarely successful in realization of growth in environments featured by both local and global competition. In addition to that, many of them are not able to attract capital investments, being at the same time less inclined to risk taking or to rising of loans (Protogerou, Caloghirou \& Markou, 2015, p. 10).

The importance of culture sector on both global and national levels, as well as the fact that it has become a protagonist of economic development, especially in developed market economies, is presented by statistics published by the most outstanding periodicals of the domain. The average participation of the creative sector gross value added totals around 6\% in Australia (2000-2005), around 7.3\% in Great Britain (2005), 13\% in Canada (1981-2007), 7.75\% in the USA (1997-2005), 2.6\% inthe EU-25 (1999-2003). The average growth of gross value added generated by the sector totaled around $6 \%$ (1997-2005) in Great Britain, 7\% in the USA (1977-2001), 10.4\% in Australia (2000 2005), 13.4\% in Singapore (1986-2000), 4\% in Canada 1995-2007), 5.4\% inthe EU-25 (1999-2003) (UNDP/UNCTAD, 2008, p. 106).

Creative industries considerably contribute to production, added value, income and balance of payments. UNDP (UNDP/UNESCO, 2010, p. 30) estimated that the average participation of these industries innational GDPs ranged from 2 to 6 per cent, depending on standards applied. In 2002 culture industry participated in GDPs of Canada and Great Britain 3.5\% and 5.8\% respectively. The above results in conclusion that creative economy considerably contributes to economic growth of the above mentioned countries.

The importance of creative economy to national economic development was illustrated by the following UNCTAD statistics (UNDP/UNESCO, 2013, pp. 162-163): global trade in creative goods and services reached record USD 624 billion in 2011 considerably more than USD 559.5 billion in 2010. Global exports of goods and services in the domains of arts and crafts, books, graphic and interior works, fashion, cinema, music, new media, printed media and visual and audio-visual products, increased in 2011 as compared to both 2010 (USD 559 billion) and 2009 (USD 536 billion). 
Creative industries make their contributions to growth, creation of new jobs and internationalization of businesses. They make a dynamic part of economy since they are more resistant to recession as compared to the other sectors. In times of financial and economic crises these industries are even more attractive since they are generally perceived as sources of potential new employments and business initiatives (Henry \& De Bruin, 2011, p. 55). According to the available 2011 statistics, creative EU-27 industries realized total value of EUR 558 billion, which makes around 4.4\% of total European GDP and 8.1 million full time jobs (Protogerou, Caloghirou \& Markou, 2015, p. 2). The data stated above point at the importance of creative industry in Europe.

The leading role in the changing World is played by „creativeindustries “ with trade in goods superseded by an economy based on ideas, i.e., on knowledge and information. Creative industries make a new economic model featured by self-employment, autonomy and flexibility, highly educated workforce comprising highly motivated „freelancers“ included in teams and networks of specialists and experts.

On the basis of acquired knowledge, applied experience, technology and professional skills the creative capital is created, making itself a main promoter of economic growth. States able to attract these "creative resources" will develop much faster than the others. Many data published in UNCTAD and UNDP reports point at the rising contribution creative sector makes to formation of global GDP. However, although the structure of creative industry is quite similar in developed and developing countries, there are some differences between particular countries concerning relative importance of various creative economy components, depending on various development phases in individual countries. Differences are reflected in starting points - whether small or middle enterprises or big corporations, public institutions of culture or individual artists and producers are considered.

The recent economic crisis resulted in lost jobs and surplus of workforce that induced many people to start their own businesses. It might therefore be held that economic crisis affected development of entrepreneurship based on stimulation of both creativity and innovativity. To that effect, authors Larroulet and Coyiomdijan (Larroulet \& Couyoumdjian, 2009, p. 84) claim that the very nature of entrepreneurship explains reasons why some countries featured by developed entrepreneurship recorded lower economic development rate than less active economies. The reason lies in the fact that opportunity entrepreneurs often take advantages of real market preferences to make their profits, as long ago, in 1942, was described by Schumpeter's theory as "a creative destruction". Kružić (2007, p. 171) points out the following: "introduction of new combinations of production factors, according to Schumpeter, is the main function of entrepreneurs with their scope of duties not including a duty to come up with new technologies or new organization by their owns, but to violate (overcome) the occurring resistance to introduction of new inventions and innovations in general, making therefore the entrepreneurship itself "a creative destruction" of individuals that perceive and realize business opportunities to make profits."

According to the "Global Entrepreneurship Monitor " $(2015$, p. 7) data, there are important oscillations not only of entrepreneurship rates by countries, but of sorts of entrepreneurs as well. Depending on a phase of entrepreneurship development the following are distinguished: early phase of entrepreneurship activity, ambitious entrepreneurs and innovative entrepreneurs. The innovative entrepreneurship rate 
is considerably variable in countries included in $\mathrm{GEM}^{3}$ sample, as well as the entrepreneurship rate. The range starts from innovative entrepreneurship activity almost absent from Brazil, to the one making above $50 \%$ of innovative activity in early phase of Chilean entrepreneurship activity (World Economic Forum \& Global Entrepreneurship Monitor, 2015, p. 17).

However, the necessity entrepreneurs, especially in periods of crisis when that is the only condition of self-supporting, do not necessarily make use of market advantages. To that effect, in the referent works could be found almost unanimous position that a crisis is much more about necessity entrepreneurship (Okamuro, van Stel \& Verheul, 2010, p. 14). Authors Roland et alia (2013, p. 28) emphasize that "in the year 2012 EU entrepreneurs had 2.7 more chance in average to be improvement-driven entrepreneurs than the necessity-driven ones". The same report bears out that the above relation was around 2 to 1 in Latin America, not including Ecuador.

Contrary to the standing opinion that processes of transformation of knowledge into innovation are more frequent in big enterprises, the most recent studies show that both small and medium enterprises (SME) are able to realize the process as well. There are instances showing that SME are sometimes more efficient in processes of creation and transformation of knowledge that necessarily implies availability of intellectual capital (http://www.madrimasd.org/revista/revista40/tribuna/tribuna2.asp).

Roots of both intellectual capital theory and knowledge management concept could be traced in works of Frederick Taylor, Joseph Schumpeter, Herbert Simon, Michael Polanyi, Robert Solow and the other economists whose ideas were widely accepted in economy of the former century. Paul Romer, prominent by his criticism of Solow`s assumptions concerning economic growth, has been considered the founder of intellectual capital concept. Romer's "New Theory of Growth" proved that competition between companies was a prompter of economic growth, as well as that competition itself was based on innovations (Kolaković, 2003, pp. 928-929).

Analyzing the economy of knowledge paradigm, Cvetković (2007, p. 39) pinpoints the following: „Underlining the role knowledge nowadays plays is a consequence of important structural changes in the frame of economic development. It was totally changed at the end of the former century and, after its transition from industrial into postindustrial economy, main resources are not material ones anymore, but resources based on application of knowledge. World-wide experience already showed that knowledge was a resource of the futureand that companies willing to surviveon the global market were due to acquire knowledge continuously and promptly." Therefore, knowledge, education, professional training, free movement of work and capital, as well as the other factors of quality became generators of growth leading into development and improvement of competitive advantage. Reality of modern times is that more than half of gross domestic products of the most developed countries are based on knowledge.

\footnotetext{
${ }^{3}$ Analysis published in 2015 report was based on the sample including 44 economies, made by merging GCI (Global Competitiveness Index) and GEM (Global Entrepreneurship Monitor) data sets.
} 
Figure 1. A simplified framework for the analysis of economic growth

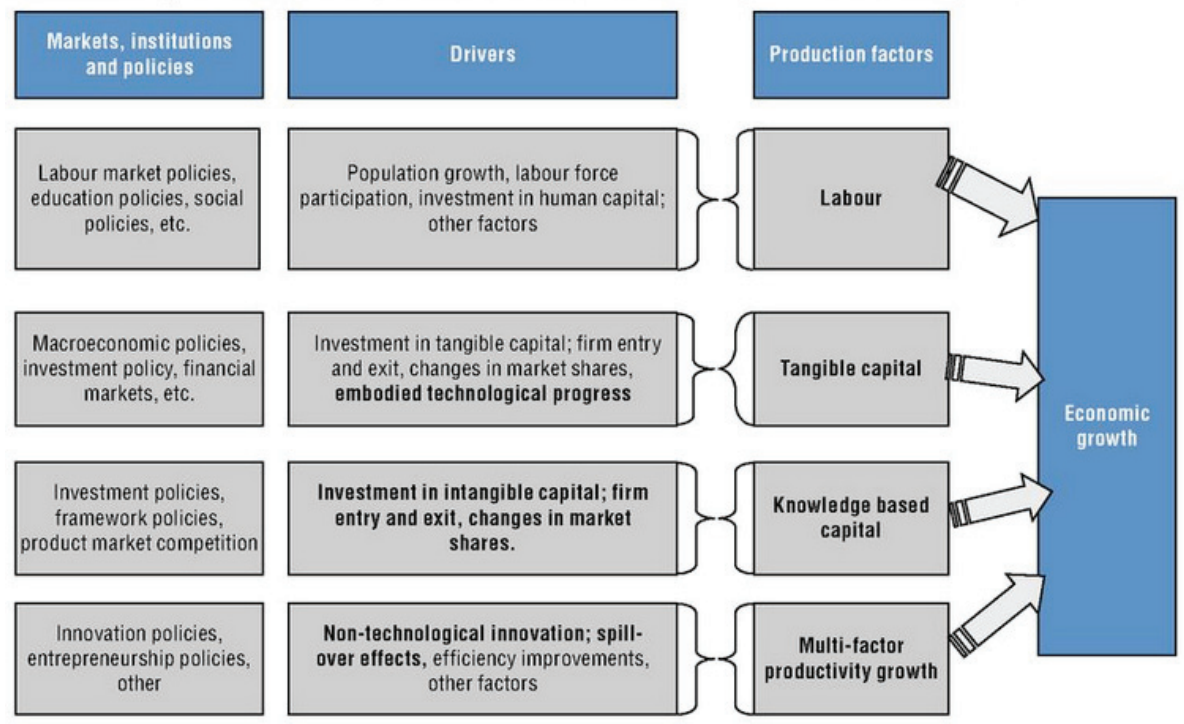

Source: OECD (2015) The Innovation Imperative Contributing to Productivity, Growth and Well-Being, OECD Publising, Paris, p. 18.; http://www.keepeek.com/DigitalAsset-Management/oecd/science-and-technology/the-innovation-imperative/the-roleof-innovation-and-the-rationale-for-public-policy_9789264239814-3-en\#page4;

$$
\text { (3.03.2016.) }
$$

The most important interest in formulation and implementation of innovation policy is based on its potential contribution to economic growth. The best way to perceive the connection between innovations and economic growth could be through function of production. Namely, economic growth is realized through inputs including work, tangible and intangible capital as well as through multifactor productivity (MFP) growth, i.e., a part of output growth which could not be explained by growth of the input factor. The following reflects innovative contribution to growth:

1. Contribution being a result of technological process recasted into physical capital. According to the most recent OECD estimates, around $0.35 \%$ of total GDP growth could be accounted to investments made in information and communications technologies capital - ICT in the 1995-2013 period.

2. Contribution being a result of investments made in intangible capital, such as R\&D, software, design, data, skills of specific companies as well as in organizational capital. OECD data indicate a constant growth of this kind of investments in OECD countries, with results of analyses made in 2012 by a group of authors (Corrado, et. al., 2012, p. 18) especially emphasized as claiming that investments into intangible capital made around $0.5 \%$ and $0.9 \%$ GDP growth in EU countries and the USA respectively in the 1995-2007 period.

3. Contribution connected with the increase of multi-factor productivity. It reflects the increased efficiency in domain of engagement of both work and 
capital due to social and organizational innovations as well as due to effects of recasting investments into technology or into knowledge-based capital $(\mathrm{KBC})$, on global level. Multi-factor productivity made more than $0.7 \%$ GDP growth in OECD countries in the period from 1995 to 2013 (OECD, 2015, p. 18).

Numerous empirical analyses have shown that innovations, in their various forms, could make their impact on economic growth depending on both level of economic development and phase of economic cycle of a country. The most important features of modern innovations refer to the following):

- Social and organizational innovations, including new business patterns, are becoming increasingly important additions to technological innovations.

- Inclusion of a wide range of participants - such as companies, entrepreneurs, funds and non-profit organizations, universities, scientific institutes and the like - which are closely connected in their business relations.

- Dynamic digital economy growth facilitating growth of mobile communication, internet communication and fast data input in both advanced and growing economies.

- Increased participation of fast growing economies, especially Chinese one which is the second biggest country to the USA by funding of R\&D projects.

- Global context relying with innovations on knowledge and ideas from all over the World.

- Appearance of "the next revolution of production" which will bring transformation of the very nature of production in businesses related to production, and also change locations of these businesses, transforming both environmental impacts they make and respective parts production and services play.

- Growing necessity for innovations that should not only support growth and creation of jobs but also enable efficient public services and efficiently cope with specific social and global challenges. (https://innovationpolicyplatform. org/content/innovation-today)

Therefore, the intellectual capital paradigm is based on capability to get adapted, to learn and develop new knowledge. According to Sundać and Fatur, the authors (Sundać \& Fatur, 2004, p. 89): "Only a synergy of human, structural and consumercapitals could result in adamantintellectual capitalto be a source of a company`s competitive advantage". Human capital is often both a key factor and a bottleneck of efficient application of information technology. Corporative staff and their knowledge make the biggest resource of a company. Artificially made vertical hierarchy connections cease to exist, and communication and transfer of knowledge become imperative at all levels instead.(Cvetković \& Kotlica, 2007, p. 45).

Corporative structural capital is connected to organizational capital theplatform of which includes structure of knowledge and enables coordination in the course of performing the duties within a company. Its construction comprises seven items measuring protection of innovations, adaptability and flexibility of production processes, access to information, innovation support processes, knowledge keeping routine, and the like. 
Intellectual capital makes an intangible resource creating organization`s strategic value. In times of new economy the intellectual capital concept is used as a synonym for employees able to transform knowledge and include it in value creating products and services (Navarro, Ruiz \& Peña, 2011, p. 111). Pena (Peña, 2002, p. 185) emphasizes the existence of a direct connection between human capital and positive results companies achieve.

Human capital, innovation and transfer of technology are of crucial importance to creation of intellectual capital model and its relationship network. As resulting from interchange of information and knowledge within various socio-economic circles, both value and social wellbeing are created in developed economies, in accordance with “intelligent nations" (Navarro, Ruiz \& Peña, 2011, p. 111).

We live in turbulent times featured by permanent change leading often to lower or higher recessions in particular countries, regions or at the global level. With a view of getting accommodated to requirements of international competition and surpassing states of crisis, intellectual capital, technological development and research gain their special importance.

\section{Surpassing crises through investments in innovation and development}

Global economic crisis made its various intensity impactson almost all economies of the World, on all casts and individuals. There is virtually not a single country, developed or industrial, that did not avoid impacts of spreading crisis. Out of 20 developing countries with economies that experienced serious deterioration of business conditions, seven were European and Central Asian and eight Latin American ones (World Bank, 2008, p. 2). Crisis caused the decrease of macroeconomic aggregates and indexes of almost all countries of the World. Crisis brought a deep decline of economic activity, production and exports, productivity, employment, direct foreign investments and standard of living.

Global economic crisis is considered the one which is not of predominantly cyclic character, in spite of conventionally accepted rule of its regularity. Its cyclic character arises from the very nature of economic system aiming to get modified and developed. Modern crisis is, above all, a system one since nowadays big and heavy structural problems are typical to global economic crisis and they penetrate the very essence of operation of the global economic system.

In the initial phase of its manifestation the crisis took a form of financial one, regarding that it directly influenced various financial institutions. At the very moment when effects of the crisis were felt within real economy as well, it became an economic crisis. It started in 2007 as the one resulting from endeavor of financial institutions to diversify risks and convert insolvent assets into solvent papers on the one hand, and from existence of insufficient and low quality information on, often very complex, securities of the kind - on the other hand.

Due to fiscal stimulation in developed countries more severe consequences were avoided. Observed at the time length, both global growth and development require a range of measures, i.e. "to get initiated cleaning of disputable and toxic assets of financial institutions finished,and to perform institutional improvement in financial sector whose 
cancelations generated global financial crisis, and afterwards economic crisis as well" (Bošnjak, 2011, p. 4).

Financial innovations that lead into expansion of so-called subprime (secondary) credits in the USA caused a discrepancy between financial and real spheres. Incongruity between financial and real sectors that resulted in deceleration of real sector growth is considered the main cause of global financial and economic crisis. For instance, financial sector share in the USA corporate profits was duplicated in the last two decades just before crisis itself started, and that caused a necessity of state interventionism in financial sector (Mladenović \& Kitanović, 2014, p. 5).

In distinction to financial innovations, the idea that successive waves of technological innovations represent the main agents of long-term performances of both new and existing businesses seems to be absolutely the right one. It is well known that innovations in domains of technology, processes and methodology always used to emergeand that they are certainties in modern economy of the World. The entire new way of doing business emerged in the last two centuries, together with prosperity of production, transport, services and communications. It was manifested in the form of fast subsequent cycles in a trend of exponential acceleration which was realized in the course of last few decades. However, the important lesson on history of economy reads that innovation as such does not ensure success of any particular company, be it a pioneer in application of it or nothing but the one pursuing ever changing circumstances (Helfert, 2000, p.19).

Investments in research and development (R\&D) are immanent to companies in every phase of their life, so much more because they enable creation of new products, as well as accomplishment of primacy in their own branches of business. This form of investment brought considerable results due to, inter alia, rights of protection of intellectual property of companies.

Trend of modern economy facing numerous problems and potential crisis is to increase investments in intangible assets, e. i., investments in research and development (R\&D) instead of increasing investments in material goods. This is about investments enabling creation of new products, promotion of enterprises and establishment of the leading enterprise in the respective business sector. In a word, the "innovation economy" will change the very nature of work, businesses, capital, competition, market and consumers. The key chance that innovation economy offers to individuals is a chance to create wealth the range of what has never been recorded before.

Special efforts have been made by the most developed countries of the World, including the European Union, to encourage, by virtue of numerous obstacles caused, inter alia, by states of crisis, creation of environment within which both knowledge and innovation will be stimulated (Jovetić \& Janković, 2012, p. 512). Whereas the foundation of the Europe 2020 Strategy is creation of a kind of "Innovational Union", the biggest challenge it is going to face will be the attempt to make innovations its long-term strategic priority. To that end, not only financial resources but simulative and coordinated instruments and measures of both national and regional policies are available to protagonists of innovations. 
The Main Science and Technology Indicators ${ }^{4}$ (MSTI) published preliminary data for the year 2015, showing that research and development (R\&D) budgets of OECD countries continued their decreasing trends starting from 2010, not including a short period of stabilization recorded in 2014. Out of total of analyzed countries, about two thirds of them reduced their real R\&D budgets so that estimated total value decreased by $1.3 \%$. It is forecasted that spending on research and development performed by governments and high education institutions in OECD countries is going to be calculated as decreased in 2015 as well (OECD, 2016).

Table 1. R\&D budgets - Total GBAORD (\$ million in 2010, constant prices, basic $2008=100$ )

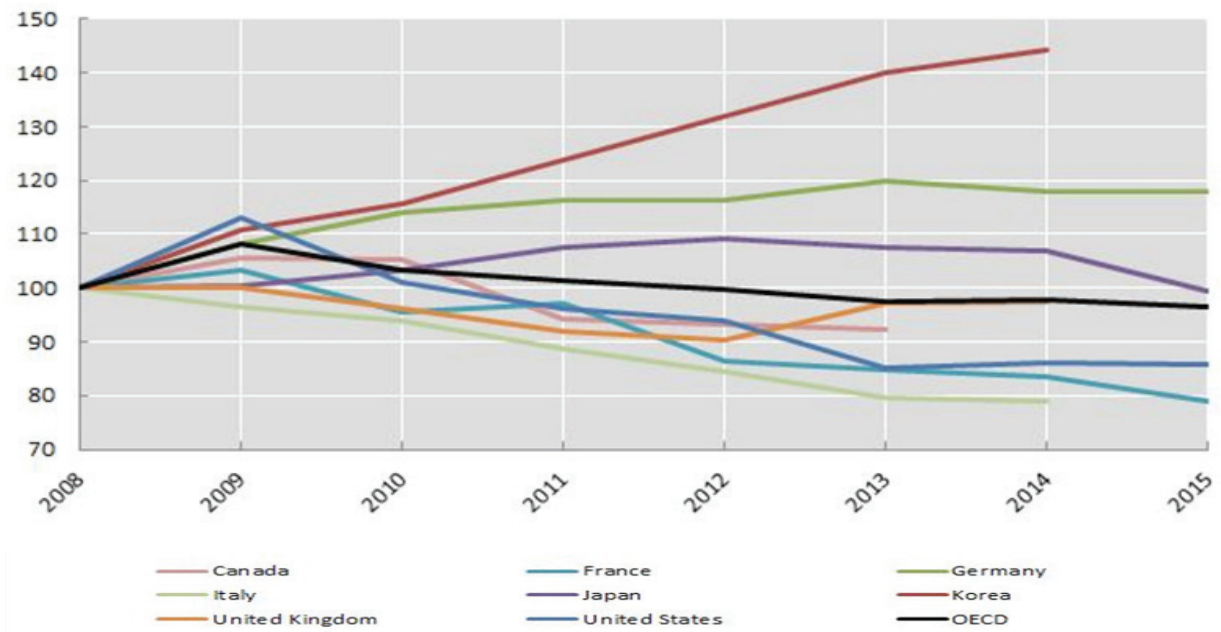

Source: OECD, calculation based on the Main Science and Technology Indicators, January 2016; http://www.oecd.org/sti/sci-tech/msti.htm

The most recent OECD data (OECD, 2016) on gross domestic expenditure on R\&D (GERD) indicate that annual GERD of OECD countries increased in 2014 in real terms by $2.1 \%$, and that the increase was slugged as compared to $2.8 \%$ in the previous year. It has been indicated that outlays for R\&D in state institutions increased to $1.0 \%$,

\footnotetext{
${ }^{4}$ Main Science and Technology Indicators (MSTI) - stands for a data base showing a range of indicators reflecting levels and structure of endeavours made by both OECD member-states and seven non-member states (Argentina, China, Romania, Russian Federation, Singapore, South Africa, Chinese Taipei) in science and technology domains, starting from 1981.
}

${ }^{5}$ GABORD - Goverment budget appropriations or outlays for R\&D 
while at the same time they slightly decreased in high education institutions $(-0.2 \%)$. GERD share of GDP remained unchanged in OECD countries, at the level of $2.4 \%$ (Table 2).

Table 2. R\&D Intensity: Gross Domestic Expenditure on $R \& D$ as percentage of GDP, 2000-2014.

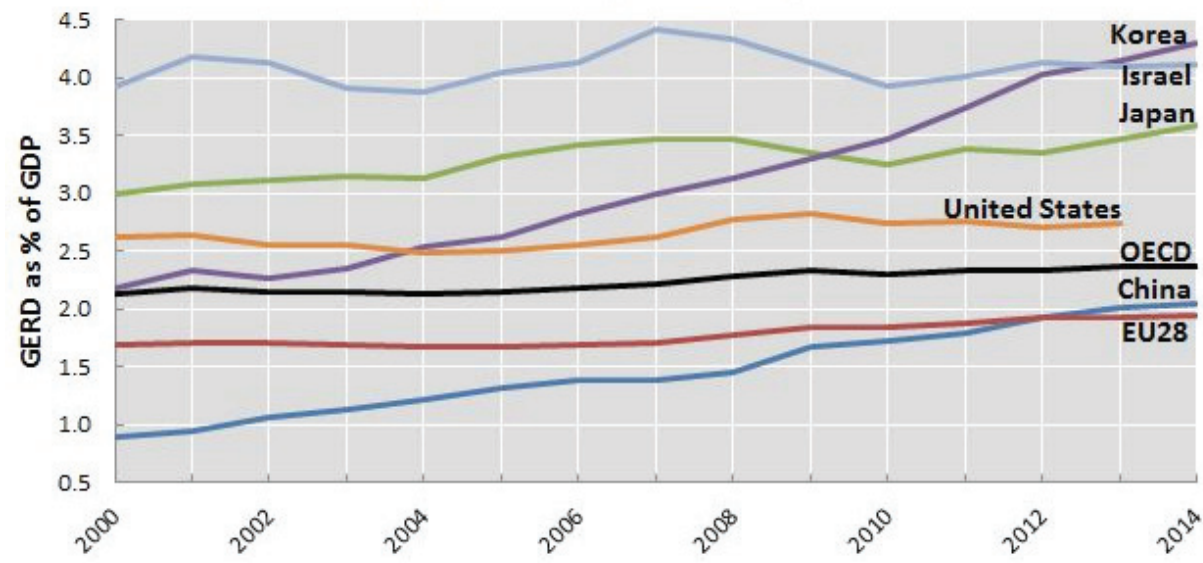

Source: OECD, the Main Science and Technology Indicators data base, January 2016; http://www.oecd.org/sti/sci-tech/msti.htm

The same source (OECD, 2016) recorded a turning point in China concerning outlays for R\&D whereas they reached the level of $2 \%$ of GDP, which was a goal established in plan for 2010. Even though GERD continued to rise quite quickly in China, at the rate of $9 \%$ in 2014, it was the lowest increase of Chinese GERD since 1996. The highest intensity of outlays for R\&D in the World recorded Korea, amounting 4.3\% in 2014. Second to Korea was Israel with the rate of $4.1 \%$.

By facing negative effects of global financial crisis, both innovation and innovation stimulation strategy took up a special and important place in government policies of many countries. As early as in 2009 OECD (Marklund, 2009, p. 7) published a study emphasizing the importance of research and innovations in overcoming of crisis. In addition to that, the study comprises measures aimed at stabilization of financial systems.

Concerning investments in innovations, OECD countries also invest in capital based on knowledge which promotes innovations, as well as in physical, i.e. material means. Development of innovations is encouraged by structural and political reforms. Structural reforms should enable maximizing of effects of investments made in knowledge, inter alia by relieving movement of both capital and workforce. Political reforms can also discourage placement of resources to nonefficient enterprises. Open markets and competition are of a special importance when it comes to expansion of innovations (https:// innovationpolicyplatform.org/content/business-environment-innovation).

The DynEmp (The Dynamics of Employment Growth) data (Criscuolo, Gal \& Menon, 2014, p. 9), recorded by OECD, comprise comparative data on proportion and lifetime of 
enterprises and on employment rates in the period from 2001 to 2011 in domains of production, civil engineering and non-financial services in 18 countries. ${ }^{6}$ In addition to the above, the project comprises the analysis of influence global financial crisis made on creation and loss of jobs.

Global economic crisis influenced relationship between creation of new jobs and various ways of losing jobs. Under the influence a drastic decline of employment rate took place, without any new conditions being made in order to get new jobs created. The data indicate that in the USA the difference in net rate of creation of new jobs between young/small and big/mature enterprises decreases cyclically. They also consider old small enterprises less sensitive to crisis then small and young ones. The crisis especially hits younger enterprises because they are deprived from access to financial funds and loans. Therefore, in a longterm, it makes an obstacle to creation of new jobs since it has considerably contributed to abolishment of already existing businesses (Criscuolo, Gal \& Menon, 2014, p. 45).

On the basis of exhaustive analysis of The Dynamics of Employment Growth project, the following conclusions can be made:

- Among small and medium enterprises (SME), young enterprises play a central role in job creation and improvement of both growth and innovations. Generally, in all countries and by lifetime, young enterprises make $17 \%$ of total employment but create $42 \%$ jobs.

- Important difference between countries is based on contribution young enterprises make in employment process.

- Many countries recorded considerable decline of start-up rate.

- Young enterprises were more damaged by impacts of financial crisis.

- Young enterprises were more influenced by financial crisis than the other ones.

- Start-up businesses in unstable sectors and in sectors manifesting higher dispersion of growth are much more exposed to influence of national policies than start-ups in other sectors.

- Public policies can help creation of potentials for growing of young, innovative enterprises. Structural reforms in the form of functional improvements of product, work and capital markets, as well as promotion of adequate legislation, are of crucial importance to the matter (Criscuolo, Gal \& Menon, 2014, p. 9).

Policies applied in OECD countries are not encouraging enough concerning experiments with new ideas, technologies and business models, without which success of innovative companies is hardly possible. Young enterprises are especially important to growth of both new sectors and growing ones. However, proportion of an average young enterprise in numerous OECD countries is small, which is the fact restricting their influence in domains of innovation, economy and society.

\section{Conclusion}

The twenty-first century economies will thrive if they accept innovations in accordance to changes. If they do that, and if individuals understand and use innovation, they will be able

${ }^{6}$ Data presented by this report comprise the following countries: Austria, Belgium, Brasil, Canada, Finland, Italy, France, Hungary, Luxemburg, Japan, Netherlands, Norway, New Zealand, Portugal, Spain, Sweden, Great Britain and the United States. 
to enjoy the fruits offered by the largest generator of progress ever. The future of the World in which we operate will be based on a completely new trend, on so-calledinnovation economy. It is no longer based on capital, knowledge and natural resources only but also on a personal approach to radical innovation. The time to come will be marked by radical new ideas influencing emergence of new markets, creating new industries and attracting new investments. Traditional factors determining success of an economy will be not sufficient anymore.

Small and medium companies in the creative industries face similar problems as those faced by small businesses in other domains of economy. One of the major constraints in efforts to transform a creative idea into merchandise or service is aggravated access to capital. Development of creative entrepreneurial projects is not possible without providing of the necessary financial resources. Creative SMEs operate better in countries with financial sectors adjusted in order to finance small and medium enterprises and where creative industries are officially recognized. In this regard, small and medium enterprises in most developing countries are at disadvantage, especially because the concept of creative industries itself is still quite new.

Creative industries are important segments of national economies. The increase of developmental performances in creative industries is expected in both developed and developing countries as well as in countries in transition. By making their contributions to economic development of countries, creative industries affect the growth of creative capital and establishment of creative class which a priori makes an investment attracting factor, reducing therefore negative effects of potential states of crisis.

The "Innovation Economy" will change the very nature of work, businesses, capital, competition, markets and consumers and enable creation of conditions for overcoming a crisis. Key option that the innovation economy provides for entrepreneurs is creation of wealth of unprecedented scale. Almost all countries of the World, faced with the problem of recession, in their efforts to overcome situations of crisis, create environments stimulating the advancement of knowledge and innovation. To this end policies of many countries are focused on innovations and the adequate stimulating strategies.

\section{References}

Bošnjak, M. (2011) Globalna finansijska i ekonomska kriza i njen uticaj na privredu $i$ finansije Srbije, Ministarstvo finansija Republike Srbije, Beograd

Bogavac-Cvetković, N. (2010) Finansijske strategije korporacija, Megatrend Univerzitet, Beograd.

Criscuolo, C., Gal. N. P., Menon, C. (2014) The Dynamics of Employment Growth: New Evidence from 18 Countries, OECD Science, Technology and Industry Policy Papers no. 14, OECD Publishing

Corrado, C, et. al. (2012) Intangible capital and growht in advanced economies: Measurement methods and comparative results, IZA Discusion Papers, No 1154, OECD Publishing, Paris; prema: OECD (2015) The Innovation Imperative Contributing to Productivity, Growth and Well-Being, OECD Publising, Paris

Cvetković, N., \& Kotlica, S. (2007) Nova ekonomija u svetu koji se menja, Megatrend univerzitet, Beograd 
Henry, C., De Bruin, A. (Eds.) (2011) Entrepreneurship and the Creative Economy: Process, Practice and Policy, Cheltenham, UK, Edward Elgar

Helfet, E. (2000) Financial Analysis Tools and Techniques: A Guide for Managers, McGraw-Hill, New York

Jovetić, S., Janković, N. (2012) Znanje i inovativnost kao faktor društvenoekonomskog razvoja zemlje: statističko-ekonometrijski model, Ekonomske teme, Godina izlaženja 50, br. 4, Ekonomski fakultet, Univerzitet u Nišu

José Luis Alfaro Navarro, Víctor Raúl López Ruiz, Domingo Nevado Peña (2011) Estimation of intellectual capital in the European Union, Zbornik radova Ekonomskog fakulteta Rijeka, Vol. 29 , sv. 1, Rijeka.

Kolaković, M. (2003) Teorija intelektualnog kapitala, Ekonomski pregled, Vol. 54 (11-12), Hrvatsko društvo ekonomista, Zagreb.

Kružić, D. (2007) Poduzetništvo i ekonomski rast: reaktualiziranje uloge poduzetništva u globalnoj ekonomiji, Ekonomska Misao, Praksa Dbk., God XVI. (2007), Br. 2., Savez ekonomista Srbije, Beograd.

Larroulet, C., Couyoumdjian, J. (2009) Entrepreneurship and Growth, Independent Review, Vol. 14, No (1), Oakland.

Marklund, G. (Eds.) (2009) Fight the Crisis with Research and Innovation? Additional public investment in research and innovation for sustainable recovery from the crisis, Vinnova, Swedish Governmental Agency for Innovation Systems.

Mladenović, I., Kitanović, D. (2014) Teorija krize posle krize, Ekonomske teme, 52 (1), Ekonomski fakultet, Niš

Nikolić, M., Despotović, D., \& Cvetanović, D. (2015). Prepreke inoviranju malih i srednjih preduzeća u Republici Srbiji. Ekonomika, 61(4), 89-96

OECD (2015) The Innovation Imperative Contributing to Productivity, Growth and Well-Being, OECD Publising, Paris.

OECD, baza podataka Main Science and Technology Indicators, January 2016; http:// www.oecd.org/sti/sci-tech/msti.htm; ( 21.03.2016.)

Okamuro, H., van Stel, A., Verheul, I. (2010) Understanding the drivers of an entrepreneurial economy: lessons from Japan and the Netherlands, CCes Discussion Paper, Series 36, Centre for Research on Contemporary economic systems

Protogerou, A., Caloghirou, Y., Markou, F. (2015) Entrepreneurial Ventures in the Creative Industries: a Case Study Approach, Proceedings of the $27^{\text {th }}$ Annual EAEPE Conference 2015, Scuola Politecnica of the University of Genova, Genova, Italy.

Peña, I. (2002) Intellectual capital and business start-up success, Journal of Intellectual Capital, Vol. 3 (2), The Emerald Group Publishing.

Roland, S., Kelley, D., Kew, J., Herrington, M., Vorderwülbecke, A. (2013) Global Entrepreneurship Monitor 2012 Global Report, Retreived 9 ${ }^{\text {th }}$ of November, 2013, New York

Schumpeter, J. (1989) Theory of Economic Development: An Inquiry into Profits, Capital, Credit, Interest, and the Business Cycle, New Brunswick, New Jersey: Transaction Publishers, 1989 (1934) 
Sundać, D., Fatur, I. (2004) Intelektualni kapital - čimbenik stvaranja konkurentskih prednosti i logističkog poduzeća, Ekonomski pregled, Vol. 55 (1-2), Zagreb.

UNDP/UNCTAD (2008) Creative Economy Report 2008: The Challenge of Assessing the Creative Economy: Towards Informed Policy-making, UNDP\&UNCTAD, New York.

UNDP/UNESCO (2010) Creative Economy Report 2010 - A Feasible Development Option, New York, USA

UNDP/UNESCO (2013) Creative Economy Report 2013 - Widening Local Development Pathways, Special Edition, New York, USA

World Bank (2008) Global financial crisis and implications for developing countries, São Paulo, Brazil

World Economic Forum\&Global Entrepreneurship Monitor (2015) Leveraging Entrepreneurial Ambition and Innovation: A Global Perspective on Entrepreneurship, Competitiveness and Development, New York

Global Entrepreneurship Research Association, London Business School, http://www. gemconsortium.org/docs/download/2645 (20.01.2016.)

MIOD Issue 40, january-february 2007, http://www.madrimasd.org/revista/revista40/ tribuna/tribuna2.asp (20.12.2015.)

World Bank\&OECD, https://innovationpolicyplatform.org/content/innovation-today (10.01.2016.)

Organisation for Economic Co-operation and Development, http://www.oecd.org/sti/ sci-tech/msti.htm (05.01.2016.)

World Bank\&OECD, https://innovationpolicyplatform.org/content/businessenvironment-innovation (10.01.2016.)

Organisation for Economic Co-operation and Development, http://www.oecd.org/sti/ dynemp.htm (05.01.2016.)

World Bank \& OECD, https://innovationpolicyplatform.org/content/businessenvironment-innovation, (05.01.2016.) 